\title{
Survey on Raw Milk Quality in Kosovo
}

\author{
Hysen Bytyqi ${ }^{1 *}$, Stefan Bigler ${ }^{2}$, Skender Muji ${ }^{1}$, Ardita Jahja ${ }^{1}$, Urs Zaugg ${ }^{2}$ \\ ${ }^{1}$ Faculty of Agriculture and Veterinary, University of Pristina, Pristina, Republic of Kosovo; ${ }^{2}$ Swiss College of Agriculture, Zol- \\ likofen, Switzerland. \\ Email: "hysen.bytyqi@uni-pr.edu
}

Received March 9 $9^{\text {th }}$, 2011; revised April 25 th $^{\text {th }}$ 2011; accepted May $3^{\text {rd }}, 2011$.

\begin{abstract}
In Kosovo, a new regulation on quality standards and grade of fresh milk is valid since January 1, 2007. The regulation was based on the respective EU-regulation and has an ambitious time frame with a transition period of only three years. In order to estimate the impact of this new regulation, a survey on the quality of raw milk delivered to the Kosovar dairies was carried out from January to May 2007. The aim was to get a reliable picture of the current raw milk quality in the dairy channel in Kosovo, to discuss the findings with the relevant actors of the dairy sector and the government, and to draw the necessary conclusions. In total 364 milk samples, from the leading 14 dairies constitute the basis for the statistical analyses of this study. The four most important parameters of raw milk quality: TBC, SCC, FP and AB were analyzed. Regarding TBC, the results show that around 20\% of samples meet the Kosovo standard $2008(<500,000$ CFU/ml) and only around 10\% meet the (higher) Kosovo standard $2009(<100,000 \mathrm{CFU} / \mathrm{ml})$ while for SCC, around $80 \%$ of the samples meet the Kosovo standard $2008(<600,000 \mathrm{cells} / \mathrm{ml})$ and $66 \%$ meet the (higher) Kosovo standard 2009 (<400,000 cells $/ \mathrm{ml})$. Therefore at the moment the problem of high microbiological content is more prominent than the one of high somatic cell count. Beside this, in one third of the samples, the freezing point is at least questionable. In $2.2 \%$ of the samples antibiotics could be proven-a major risk for public health. Raw milk quality in Kosovo still is very poor and must be improved in order the dairy processors be able to produce qualitatively good end products and therefore can compete with imported dairy products or export their products.
\end{abstract}

Keywords: Raw Milk Quality, Microorganisms, Somatic Cell Count, Freezing Point and Antibiotics

\section{Introduction}

High quality raw milk is a major factor on quality of dairy products. In Kosovo, a new regulation on quality standards and grade of fresh milk is valid since January 1, 2007 [1]. The regulation is based on the EU-regulation and has an ambitious time frame with a transition period of only three years. The proposed standards for Class I milk are even higher than the actual Swiss standards. It is very unlikely that the dairy industry can reach these standards in due time. Even then, the impact will not be very extensive as the Kosovar dairies only transform about $15 \%$ of the produced milk. The other $85 \%$ are consumed directly by the rural households (self subsistence farming) or sold in the so called "Green market”, where there is no official control of raw milk quality at all. We can assume that if Kosovar dairy farmers can't fulfill the requested standards, they will shift to the informal market-a situation that cannot be welcomed by the authorities due to public health reasons.

Till spring 2007 no laboratory for raw milk analysis existed in Kosovo. In consequence, knowledge of the current situation regarding raw milk quality along the value chain (dairy farm, milk collection points, transportation, dairy plants) was scarce and very insecure. Within the Kosovo Dairy Consolidation Program (KDCP), a survey on the quality of raw milk delivered to the Kosovar dairies was carried out from January to May 2007. The aim was to get a reliable picture of the current raw milk quality in the dairy channel in Kosovo, to discuss the findings with the relevant actors of the dairy sector and the government, and to draw the necessary conclusions.

This paper gives a general introduction regarding raw milk quality in Kosovo, an actual overview of literature, describes the material and methods, presents the results and the discussion and draws first conclusions.

Microorganisms (TBC) in the raw milk derive from various sources of contamination, such as the udder from non healthy cows, from the surface of the teats, from the air and from milk contacted surfaces of the 
milking, storage and transport equipment [2]. Milk in the udder of a healthy cow is more or less free from bacteria. The first contamination of the milk with bacteria happens in the teat channel [2,3]. By passing the teat channel, the milk is contaminated with 100 - 1000 CFU (Colony Forming Units)/ml [2] or 100 - 10,000 CFU/mL [3]. The milk from mastitis cows has a significant higher content of bacteria [3].

During milking process the milk is contaminated by the skin of the udder, unclean milking equipment, brittle gum parts of the milking system or dust and dirt in the air of the cow-shed. Low bacterial load in fresh extracted milk is an indicator for a hygienic milking process [3]. The increase of microorganisms in the milk from milking to processing depends mainly from the storage temperature. By cooling the milk below $4^{\circ} \mathrm{C}$, after $24 \mathrm{~h}$ no significant reproduction of the bacteria is detectable [3]. If the cooling is not done appropriate (e.g. only to around $6.5^{\circ} \mathrm{C}$ ), the number of psychotroph microorganisms increases, even if this is not their optimal temperature [2]. During the yoghurt production process a heat treatment of the process milk at $85^{\circ} \mathrm{C}-95^{\circ} \mathrm{C}$ is needed. This temperature is sufficient to destroy the most vegetative bacteria in the raw milk. However, enzymes (peptidases, hydrolases and lipases) of some pseudomonas spp. are heat stable and can survive easily the heat treatment, needed for yoghurt [4].

Regarding the production of pasteurized milk, the thermoduric bacteria are important, such as sporeforming bacteria from the genus bacillus and clostridium enterococcus and streptococcus thermophilus as well as micrococcus and coryneform bacteria [2,5] write: "Psychotrophic gram-negative bacteria produce heat stable proteases and lipases that may produce off-flavour issues later during the shelf life of pasteurized milk". They also state that spores are a much more difficult problem for fluid milk shelf life than vegetative bacterial cells. Regarding cheese production, a high level of bacteria count has a negative effect caused by heat resistant, proteolytic and lopolytic enzymes which have an influence on sensorial properties of the end product [3]. Moreover a high content of psychotroph bacteria's may result in disturbance of acidification and ripening anomalies with a sensorial defect as a consequence. Furthermore, information like increased rennet coagulation time and less yield caused by high bacteria count, could be found in the literature [3].

The standards according to current valid legislation in Kosovo [1] are reflected in Table 1 for bacterial content.

The causes of a high SCC can be divided in three different factors [2].

- Mastitis (infection of the udder with mastitis causes
Table 1. Standards for CFU/mL according to current legislation in Kosovo.

\begin{tabular}{lllll}
\hline Year & Extra Class & Class I & Class II & Class III \\
\hline 2007 & $<100,000$ & $<200,000$ & $<500,000$ & $>500,000$ \\
2008 & $<80,000$ & $<100,000$ & $<200,000$ & $<500,000$ \\
2009 & $<50,000$ & $<80,000$ & $<100,000$ & \\
\hline
\end{tabular}

(Source: [1])

\section{micro-organisms)}

- Physiological factors (stage of lactation, race or age of the animal)

- Stress factors

A high number of somatic cells in milk is primary an indicator of infection of milk cows with mastitis caused by microorganisms [2]. Sub clinic mastitis is always related to lower milk yield, changes in milk composition, derogation of processability, reduced yield of protein products and hygienic relevant risks caused by pathogenic microorganisms [2]. The most important negative effects during processing of milk with a high amount of somatic cells are lower yield, reduced shelf life and unwanted sensorial properties of the end product. A high amount of somatic cells in the milk retards the activity of yoghurt cultures [4], and can inhibit the fermentation of yoghurt [6] examined the effects of SCC in milk on physical and chemical characteristics of yoghurt. They found out that an increased amount of SCC leads to an increase of Free Fatty Acid in the yoghurt during storage and may result in decreasing shelf life of yoghurt [7] report that the quality of skimmed yoghurt which is produced from skimmed milk with an amount of SCC lower than $2.5 \times 10^{5}$ cells/ml was organoleptically superior, in comparison to parallel produced yoghurt with a SCC higher than $2.5 \times 10^{5}$ cells/ml. But because of conflicting results this effect could not be conclusively demonstrated. However [8] analyzed the sensory evaluation of whole yoghurt produced from milk with different somatic cell counts. They concluded that yoghurt produced from milk with SCC > 800,000 cells/ml showed a significant decrease in sensory quality, especially in relation to consistency (after 20 days of storage at $5^{\circ} \mathrm{C}$ ) and taste (after 30 days of storage). Based on that result he recommends that raw milk as raw material for yoghurt should not contain more than 400,000 cells $/ \mathrm{ml}$. They analyzed the effect of SCC of the shelf life of pasteurized milk. After 14 and 21 days of storage under refrigerated conditions, the pasteurized milk produced from milk with a high level of SCC, showed a significant sensorial defect, which includes rancidity, bitterness and astringency. They conclude that the sensorial defect was probably caused by lypolitic and proteolitic enzymes. Because of mastitis causes changing of many milk properties, mastitis milk has as well a negative in- 
fluence of the cheese manufacturing, such as increasing of the rennet coagulation time, curd firmness, whey expulsion and rate of acid development. A high amount of SCC in milk results in lower flavour, body and texture grades [7]. The standards according to current valid legislation in Kosovo [1] are reflected in Table 2 for SCC.

For comparison, standards in Switzerland, the European Union and Macedonia and the United States are shown in Table 3.

The freezing point of milk depends of truly dissolved components such as lactose, bulk elements and NPN fractions in milk. Those components are responsible to lower the freezing point of milk to below $0^{\circ} \mathrm{C}$. The natural freezing point of milk is between minus $0.520^{\circ} \mathrm{C}$ and minus $0.530^{\circ} \mathrm{C}$ with an average of minus $0.526^{\circ} \mathrm{C}$. Due to different feeding and stadium of lactation of the cows, substantial deviations can occur [4]. The freezing point in milk is used to detect milk dilution. A dilution of milk results in the decrease of truly dissolved components per volume unit. So the decrease of the freezing is reduced, ergo the freezing point of milk is higher in diluted milk than in undiluted milk. The limit regarding accepted freezing point in heat treated drinking milk is minus $0.520^{\circ} \mathrm{C}[4,10,13]$.

In the council directive 85/397/EEC of August 5, 1985 the limit of minus $0.520^{\circ} \mathrm{C}$ for raw milk is defined(The Council of the European Communities, 1985).

Table 2. Standards for SCC/mL according to current legislation in Kosovo.

\begin{tabular}{clccc}
\hline Year & Extra Class & Class I & Class II & Class III \\
\hline 2007 & $<400,000$ & $<500,000$ & $<600,000$ & $>600,000$ \\
2008 & $<300,000$ & $<400,000$ & $<500,000$ & $<600,000$ \\
2009 & $<200,000$ & $<300,000$ & $<400,000$ & \\
\hline
\end{tabular}

(Source: [1])

Table 3. Standards according to legislation of raw milk in different countries.

\begin{tabular}{lll}
\hline Country & TBC (CFU/ml) & $\begin{array}{l}\text { SCC } \\
\text { (cells/ml) }\end{array}$ \\
\hline CH & $<80,000$ & $<350,000$ \\
& $<100,000$ (impulses) & \\
EU & $<100,000$ & $<400,000$ \\
Macedonia (at the mo- & $<3,000,000$ (before & \\
ment in the process of & $2006)$ & $<400,000$ \\
$\begin{array}{l}\text { acceptance the EU stan- } \\
\text { dards) }\end{array}$ & $<1,000,000$ (since 2006) & \\
$\begin{array}{l}\text { United States of America } \\
\text { (grade “A” raw milk and } \\
\text { milk products for pas- } \\
\text { teurization, ultra pas- }\end{array}$ & $\begin{array}{l}100,000 \text { (individual } \\
\text { producer, not commin- } \\
\text { gled with milk from } \\
\text { other producers) }\end{array}$ & \\
processing) & $\begin{array}{l}\text { 300,000 (commingled } \\
\text { milk prior pasteuriza- }\end{array}$ & \\
\hline
\end{tabular}

(Source: [9-12])
In German regulations from $1993[13,14]$ as well in the EU directive [10] the limit for freezing point for raw milk is not defined, but dairies are obliged to analyze it. In practice, the limit of minus $0.515^{\circ} \mathrm{C}$ is used as reference value [13].

But not only dilution of the milk with water influences the freezing point of the milk. A shortage of energy and surplus of protein through false feeding of the cattle can lead to a higher freezing point of the milk $[2,13]$. To find out reasons of high freezing point in raw milk, in Bavaria (Germany) a survey was carried out. The results of this survey show that out of 104 complaints regarding freezing point, 84 were caused by false feeding of the cows [13]. He reports that the freezing point of raw milk is influenced by the stadium of lactation and the season. He urges that one has to be very carefully with terms like diluting or foreign water content in raw milk based only of a freezing point higher than minus $0.515^{\circ} \mathrm{C}$.

Milk is contaminated with antibiotics or sulfonamides mainly after treatment of cows against mastitis. Residues of antibiotics are dangerous for consumers and result in serious problems during processing of the milk. The admittance of antibiotic residues can lead to direct health problems such as damage of marrow (Chloramphenicol) and can be a reason for allergic reactions. Other hazard for the health is abetting the cultivation of antibiotic resist microorganisms. Problems during processing of milk occur during production of fermented milk products, caused by inhibition of the wished microorganisms such as added cultures [2]

\section{Material and Methods}

To answer the hypothesis raised, it was decided to analyze bulked milk on milk tank level. At the beginning, around 500 existing milk tanks were estimated for Kosovo and a random sampling was planned. The list of milk tanks finally showed that there were only around 100 tanks installed-much less than predicted. A random sampling therefore was not necessary and the overall sampling could start in January 2007. The organizational matters were solved together with Land o' Lakes, Skopje and the dairies (e.g. sampling, handling of samples, collection of samples, analysis of samples, cost of analysis, etc.). In total 364 milk samples-from 94 different milk tanks from the leading 14 dairies_-constitute the basis for the statistical analyses of this study. Around $70 \%$ of the raw milk of the dairies in Kosovo was therefore included in the survey. The milk for home consumption and the milk that is sold at the so called "Green market" were not included. In these channels, the situation on quality aspects still is very unsure.

Definition of Raw Milk Units (RMU): One RMU is a 
defined entity of milk which is delivered to a milk processor. This entity of milk is bulked in a tank like a milk collection tank, a milk reception tank, a milk tank in a milk collection centre or a farmer tank.

Definition of delivering system: The supply of fresh milk to the milk processors in Kosovo is not yet standardized. Not only different kinds of milk tanks exist, moreover different ownership and different delivering system are also known. Therefore six different kinds of milk delivering systems were defined. The defined delivering systems are shown in Table 4. For each delivering system it was defined where and when the sample had to be taken.

Definition of regions: To see differences in milk quality in the different regions of Kosovo, the whole Kosovo was divided in five regions: Prishtina, Sharri, Dukagjini, Gjilani and Shala region covering 84, 112, 80, 59 and 28 milk samples, respectively.

Sample taking, Collection, Transport, Analyses (QC Lab, Land o' Lakes): The samples were taken by defined persons from the dairy in which the milk is delivered. These persons were trained by KDCP in order to take samples in an appropriate way. For taking samples in the field, cooling boxes with sufficient cooling elements and one way sample cups were distributed to the dairies. On sampling days, the samples were collected through KDCP staff. Therefore cooling boxes with even more cooling elements were used to guaranty the cooling chain to the laboratory. The samples were delivered always within 12 hours after sample taking to the Quality Control Laboratory (QC Lab) Land o’ Lakes in Skopje. In order to reach this time, one round of the survey was done on two following days. In order to get reliable results, the QC Lab in Skopje was chosen, since this laboratory

Table 4. Milk delivering systems and their definition.

\begin{tabular}{|c|c|}
\hline Name & Definition \\
\hline $\begin{array}{l}\text { Milk Collection } \\
\text { Tank (MCT) }\end{array}$ & $\begin{array}{l}\text { This tank is owned by the dairy processor. The } \\
\text { MCT is collecting the milk from different } \\
\text { small farmers }\end{array}$ \\
\hline $\begin{array}{l}\text { Milk Reception } \\
\text { Tank (MRT) }\end{array}$ & $\begin{array}{l}\text { The milk tank is installed in the dairy plant } \\
\text { and used to store milk which is delivered from } \\
\text { the farmers directly to the dairy plant }\end{array}$ \\
\hline $\begin{array}{l}\text { MCC Tank } \\
(\mathrm{MCC}-\mathrm{T})\end{array}$ & $\begin{array}{l}\text { The milk tank is located in a MCC, and the } \\
\text { milk is collected by a dairy processor owned } \\
\text { vehicle }\end{array}$ \\
\hline $\begin{array}{l}\text { MCC Transport } \\
\text { Tank (MCC-TT) }\end{array}$ & $\begin{array}{l}\text { The MCC-TT is installed of a transport vehi- } \\
\text { cle which is owned by the MCC }\end{array}$ \\
\hline $\begin{array}{l}\text { Farmer Tank } \\
(\mathrm{F}-\mathrm{T})\end{array}$ & $\begin{array}{l}\text { The milk tank is located at farm, and the milk } \\
\text { is collected by a dairy processor owned vehi- } \\
\text { cle }\end{array}$ \\
\hline $\begin{array}{l}\text { Farmer Transport } \\
\text { Tank (F-TT) }\end{array}$ & $\begin{array}{l}\text { The F-TT is installed of a transport vehicle } \\
\text { which is owned by the Farmer }\end{array}$ \\
\hline
\end{tabular}

is ISO 9001:2000 certified. Furthermore they are currently implementing EN ISO 17025 Standards, which is a standard for laboratory accreditation.

Analysing Methods: The four most important parameters of raw milk quality: CFU, SCC, FP, and AB, were analyzed (Table 5). For statistical analysis excel was used.

\section{Results}

The results of analyses for bacterial content according to raw milk quality standards in Kosovo are shown in the Figure 1. The analyses show that only 80 and 35 samples were below 500.000 and 100.000 , CFU/mL, respectively. Below were shown the overall results and some detailed analysis afterwards depicting that only around 50\% of the samples were classified as $>3.000 .000 \mathrm{CFU} / \mathrm{mL}$. The other $50 \%$ were above $3.000 .000 \mathrm{CFU} / \mathrm{mL}$, the exact distribution cannot be given as the range of analysis stopped at this level.

Bacterial content in raw milk by time response in Kosovo were presented in the Figure 2. Results of CFU/mL presented show an indication that there was a lot of very poor milk produced. Around 20\% would have met the Kosovo Standard 2008 (CFU < $500.000 \mathrm{CFU} / \mathrm{mL}$ ) and only around $10 \%$ meet the Kosovo Standard set for the year 2009 (CFU/mL < 100.000 CFU/mL).

Results show there was a tendency that months April, May were months with higher potential of contamination of milk with bacteria, where about $85 \%$ of milk produced compared to January and February with about $75 \%$ was $\mathrm{CFU} / \mathrm{mL}>500.000$.

In the Figure 3, were depicted the analyses of SCC according to the raw milk quality standards in Kosovo. At this moment, the problem of high microbiological content was more prominent than the one of high somatic cell count. For SCC, $80 \%$ of the samples meet the Kosovo Standard 2008 (SCC < 600.000 cells/mL) and 66\% meet the Kosovo Standard 2009 (SCC $<400.000$ cells $/ \mathrm{mL}$ ). Only 40 milk samples out of 364 , showed SCC >

Table 5. Parameters and methods.

\begin{tabular}{ll}
\hline Parameter & Method \\
\hline $\begin{array}{l}\text { Microorganisms } \\
\text { (CFU) }\end{array}$ & Petrifilm Aerobic Count (PAC) \\
$\begin{array}{l}\text { Somatic Cell } \\
\text { Count (SCC) }\end{array}$ & $\begin{array}{l}\text { Direct Microscopic Somatic Cell Count } \\
\text { (DMSCC) }\end{array}$ \\
$\begin{array}{l}\text { Freezing Point } \\
\text { (FP) }\end{array}$ & $\begin{array}{l}\text { Termistor cryoscope method (Reference me- } \\
\text { thod) }\end{array}$ \\
$\begin{array}{l}\text { Christian Hansen Antibiotic test. This is a } \\
\text { qualitative, ready to use test for detection of } \\
\text { inhibitory substances in milk. It contains } \\
\text { spores of Bacillus stearothermophilus var. } \\
\text { calidolactis [11]. }\end{array}$ \\
\hline
\end{tabular}




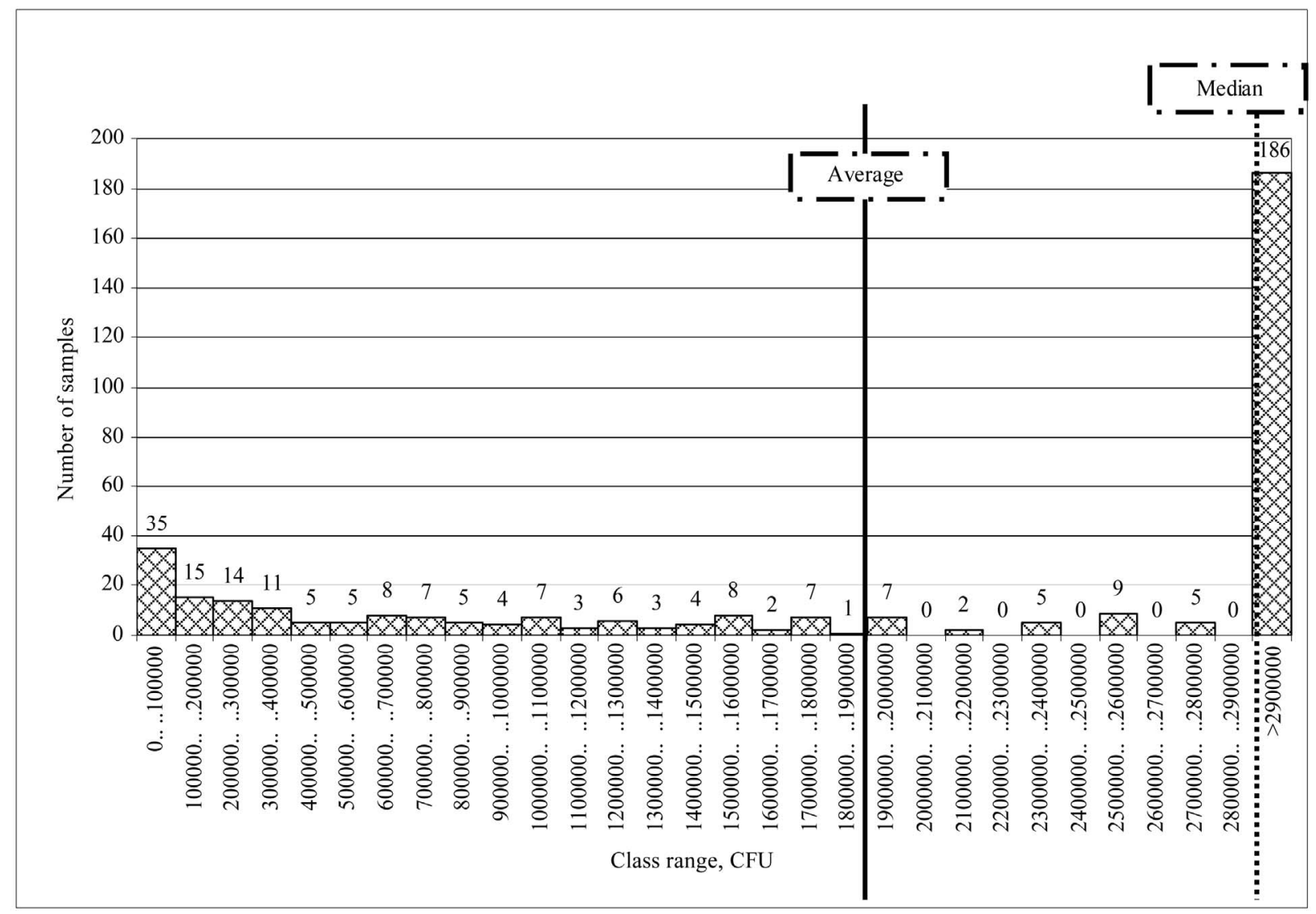

Figure 1. Analyses of bacterial content and raw milk quality standards in Kosovo $(n=364)$.

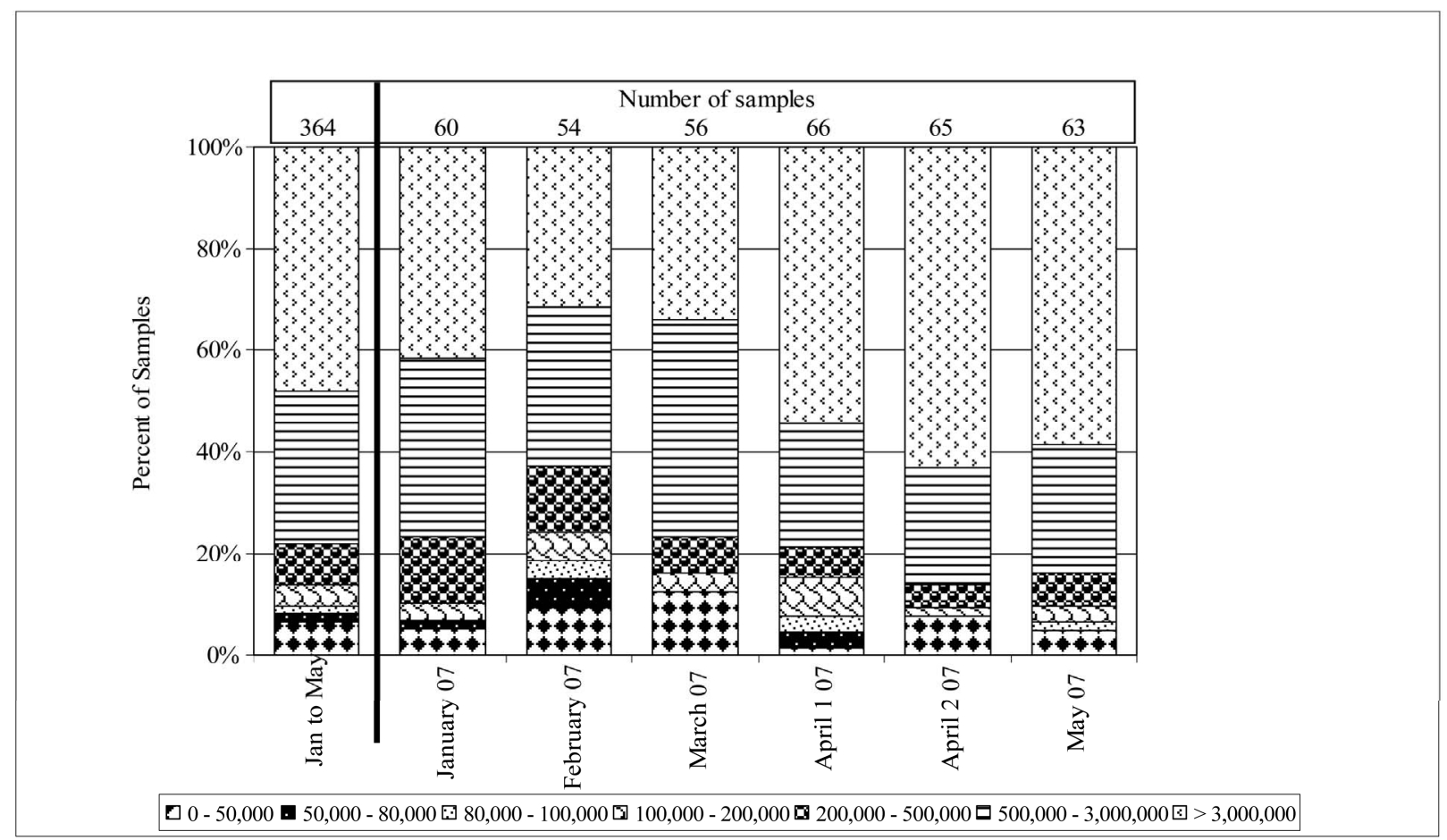

Figure 2. Bacterial count in raw milk by time response in Kosovo. 


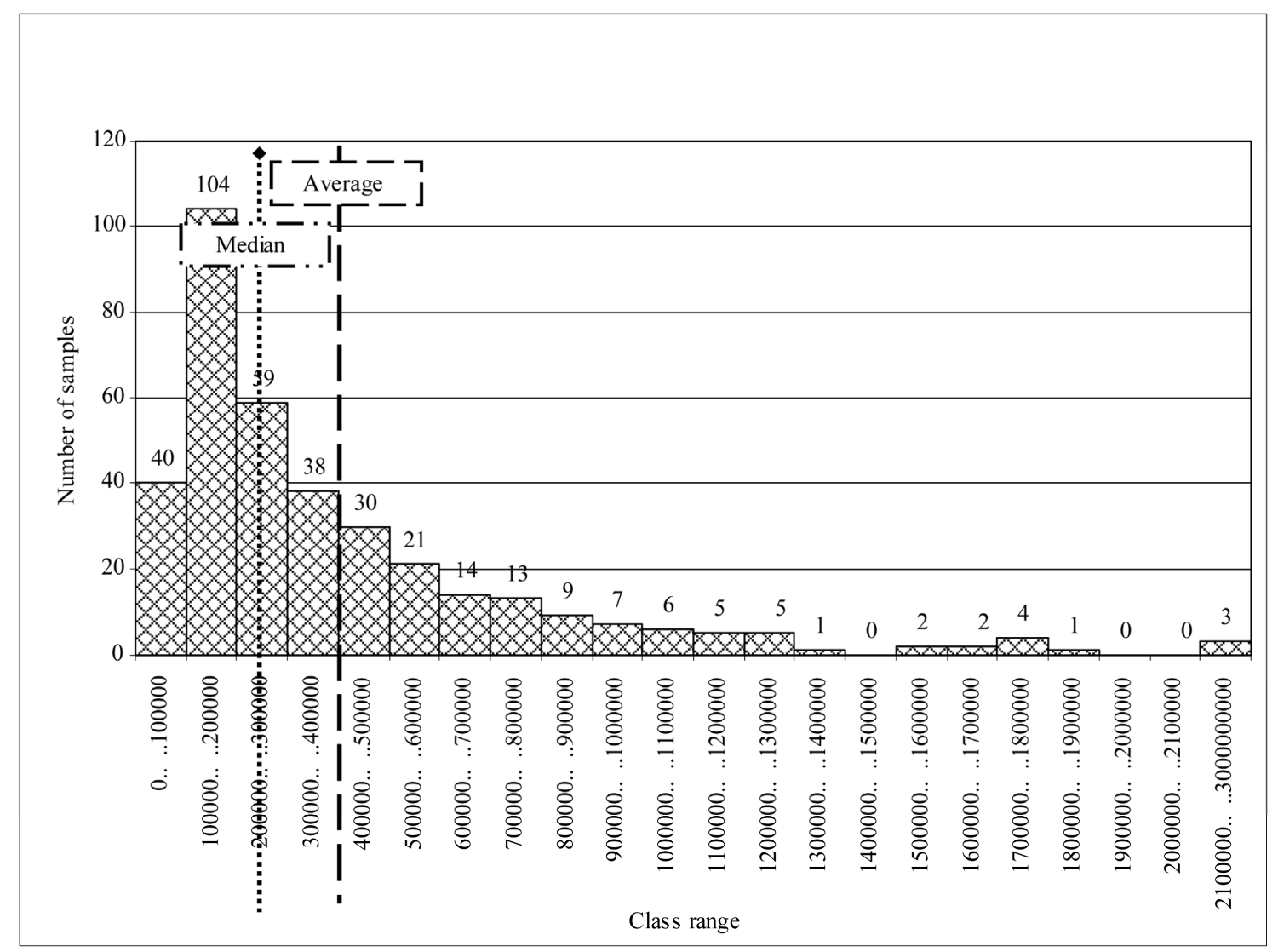

Figure 3. Analyses of SCC and raw milk quality standards in Kosovo $(n=364)$.

100.000 cells $/ \mathrm{mL}$.

Analyses of fresh milk contamination with SCC according to different delivery systems were shown in Figure 4. In total, the results indicate that about $24 \%$ of milk collected was considered as a poor hygienic milk depicting SCC > 500.000 cells $/ \mathrm{mL}$. Milk tank in MCC, farmer in dairy, and milk reception tanks seem to be more contaminated with SCC, about 38\%, 34\%, and $28 \%$ above the allowed quality standard for fresh milk (SCC > 500.000 cells $/ \mathrm{mL}$ ).

Figure 5 shows that 217 samples (57\%) had a freezing lower than minus $0.515^{\circ} \mathrm{C}$, while 110 samples (29\%) had a freezing point above minus $0.515^{\circ} \mathrm{C}$, and 52 samples (14\%) showed a freezing point even above minus $0.500^{\circ} \mathrm{C}$.

In 8 out of 364 analyzed samples, antibiotics or other inhibitors were found (results not shown). That means that around $2.2 \%$ of all analyzed samples were tested positive of chemical and physical inhibitors.

\section{Discussions}

The results give a very good overview of the actual situation of raw milk quality in the dairy sector. They were presented at the Kosovo Dairy Conference on Raw Milk
Quality in June 2007. The major issue is that the total bacteria count of raw milk still is very high—much higher than the administrative regulation will admit. Only about $50 \%$ of the samples would therefore meet the former Macedonian Standard. The conditions in Macedonian are similar to Kosovo and could be a good guideline for Kosovo.

There were also seen samples on farm level with up to $50.000 .000 \mathrm{CFU} / \mathrm{mL}$, an indication that there is a lot of very poor milk produced.

We can assume a seasonal pattern with better milk quality in the cold season - an issue which has to be studied further in depth. If the Kosovar government sticks to this rigid standard without direct intervention in milk preservation and handling infrastructure, about $90 \%$ of the dairy farmers delivering to the dairies will be driven out of the legal milk production. Therefore, they will have to sell their milk illegally to the dairies or on the green market-a high potential of future tensions between dairy farmers, dairies and government.

As stated by $[15,16]$, at the moment, the problem of high microbiological content is more prominent than the one of high somatic cell count. We can assume an influence of the delivering system on raw milk quality - an 


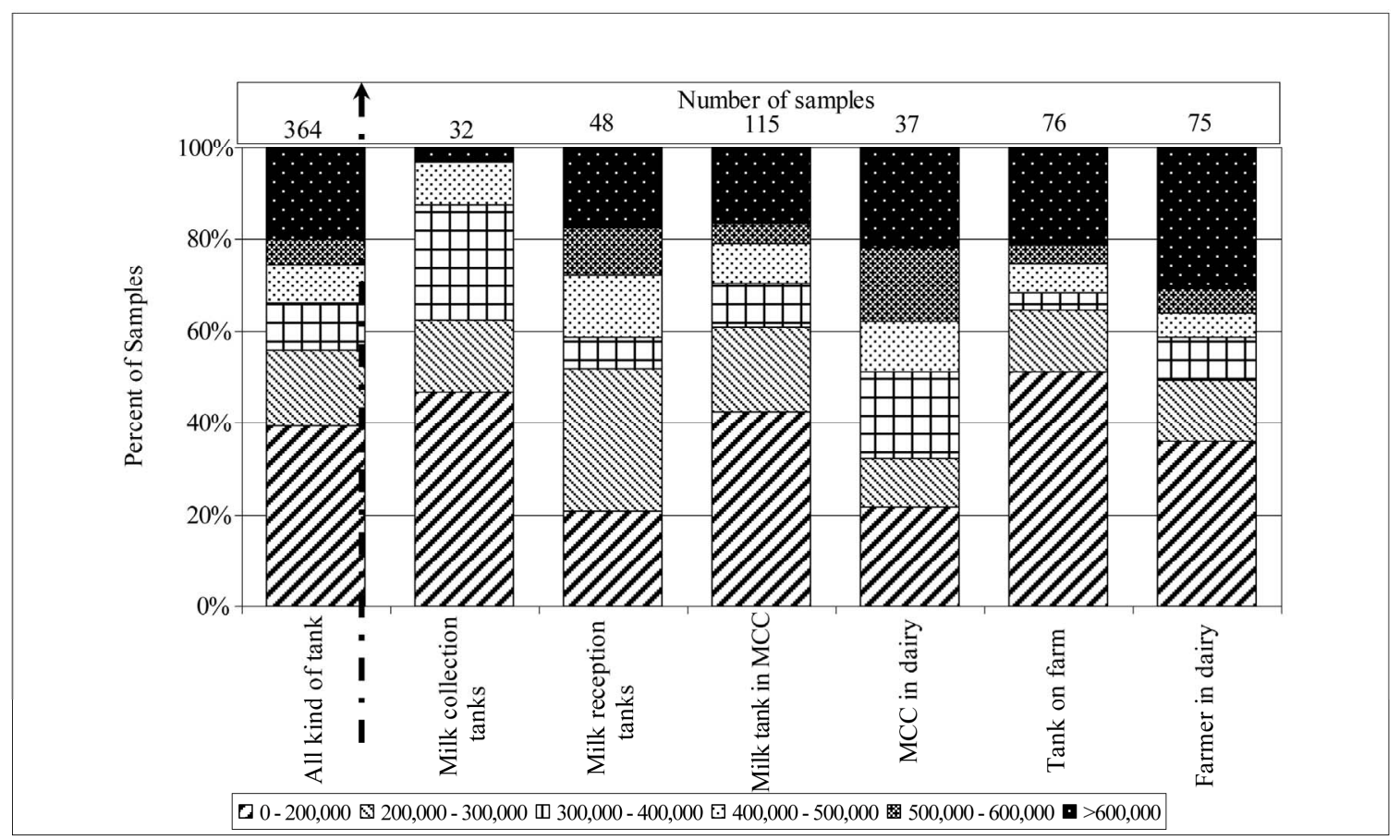

Figure 4. SCC in raw milk by sort of tank in $\operatorname{Kosovo}(n=364)$.

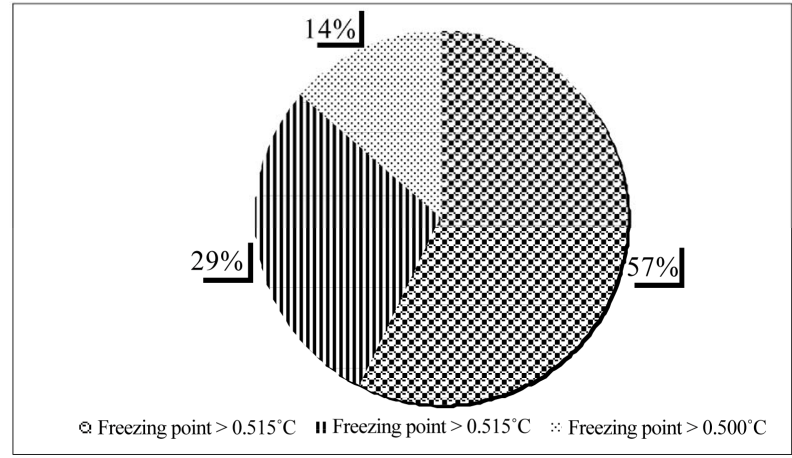

Figure 5. Freezing point of the milk $\left({ }^{\circ} \mathrm{C}\right)$.

issue which has to be studied further in depth, as it is an indicator of the herd health. It is obvious that equipments (i.e., MCC, milk tank, etc) cannot have an effect in contamination with SCC in fresh milk but this may be associated with type of delivering system (some of those receive milk from different farms and therefore possibilities of milk contamination are higher).

Regarding frizzing point on fresh milk analyses show that about half of the milk (49\%) was lower than minus $0.520^{\circ} \mathrm{C}$ and meet the limit for processed milk and former EU regulations $[2,13,17]$. It can't definitive concluded that the high freezing point of around $36 \%$ of the samples is caused by milk diluting. One may also assume that in farm level knowledge for appropriate herd management often is missing, and because of false feeding and thus changes in milk ingredients, the freezing point is increased.

It looks that a few milk samples analyzed were tested positive of antibiotics which might present a major risk for public health.

The government is aware of the unfavorable situation, but is not willing to lower the set standards right now. It is not clear, how the standard will be controlled and how they will react if the standard is not reached. The KDPA and KAMP consider that the existing standards are too high and only additional measures and incentives, e.g. lacto-freezers on farm level, subventions on milk price could improve the situation.

\section{Conclusions}

Raw milk quality in Kosovo still is very poor and must be improved. Only with an acceptable quality, the dairy processors are able to produce good quality products and can therefore compete with imported dairy products. Clear, reliable data are a key factor for improving raw milk quality in Kosovo. To get this data at a cost efficient way, the different partners have to work together: Organization of the sampling, appropriate handling of the samples, transportation to the laboratory, analysis, feedback of the individual results, statistics on the overall results and communication of these results to the industry. Based on these results, short, medium and long-term goals can be defined and followed by the industry. The policy dialogue has to continue and the adaptation of the administrative regulations has to be discussed. The new 
Raw Milk Laboratory in Prishtina, if run well offers the possibility to get the necessary information. In the short term, the problem of low microbiological quality (high CFU) is more urgent to solve than the one of high somatic cell counts. Detailed analysis of the influence of the delivering system and the influence of the season on raw milk quality are planned. A future research project could monitor the implementation of these actions and give further insight to the economically high relevant question of raw milk quality.

\section{Acknowledgements}

The authors gratefully acknowledge to milk processing plants, milk collection points and farmers that participated to study. Special thanks go to the Kosovo Milk Processing Association and Kosovo Milk Producer Association for fretful cooperation and support during entire period of study. We are thankful to the Swiss Development and Cooperation for financial supporting.

\section{REFERENCES}

[1] Ministry of Agriculture, Forestry and Rural Development MAFRD, "Administrative Instruction MA-No. 20/2006 on Quality Standards and Grade of Fresh Milk,” 2006.

[2] A. Toepel, “Chemie und Physik der Milch,” Behr’s Verlag GmbH \& Co. KG, Hamburg DE, 2004.

[3] I. Riemelt, B. Bartel and M. Malczan, "Milchwirts- chaftliche Mikrobiologie,” Behr’s Verlag GmbH \& Co, Hamburg DE, 1996.

[4] A. Y. Tamime and R. K. Robinson, "Yoghurt Science and Technology,” Woodhead Publishing Ltd, UK, 1999.

[5] D. M. Barbano, Y. Ma and M. V. Santos, "Influence of Raw Milk Quality on Fluid Milk Shelf Life,” Journal of Dairy Science, Vol. 89, Suppl. 1, March 2006, pp. E15E19.

[6] A. M. Fernandes, F. A. C. Oliveira and G. C. Lima, "Effects of Somatic Cell Counts in Milk on Physical and Chemical Characteristics of Yoghurt," International Dairy Journal, Vol. 17, No. 2, 2007, pp. 111-115. doi:10.1016/j.idairyj.2006.02.005

[7] S. A. Rogers and G. E. Mitchel, "The Relationship between Somatic Cell Count, Composition and Manufacturing Properties of Bulk Milk 6. Cheddar Cheese and Skim Milk Yoghurt,” The Australian Journal of Dairy Technology, Vol. 49, 1994, pp. 70-74.
[8] C. A. Oliveira, A. M. Fernandes, O. C. Neto, L. F. Fonseca, E. O. Silva and S. C. Balian, "Composition and Sensory Evaluation of Whole Yogurt Produced from Milk with Different Somatic Cell Counts," The Australian Journal of Dairy Technology, Vol. 57, No. 3, 2002, pp. 192-196.

[9] EVD (Eidgenössisches Volkswirtschafts Departement), "Verordnung des EVD über die Hygiene bei der Milchproduktion (VHyMP)," 28 May 2008. http://www.admin.ch/ch/d/sr/c916_351_021_1.html

[10] Council of the European Communities, "Council Directive 92/46/EEC of 16 June 1992 Laying down the Health Rules for the Production and Placing of the Market of Raw Milk, Heat Treated Milk and Milk-Based Products," Official Journal L 268, 14 September1992, pp. 00010032.

[11] Quality Central Lab, “Laboratory Manual, Antibiotics and other Inhibitors 2004,” Quality Central Lab, 4 March 2010.

http://qclab.com.mk/english1/quality_assurance_policy.ht $\mathrm{m}$

[12] USPHS/FDA (U.S. Department of Health and Human Services, Public Health Service, Food and Drug Administration), “Grade 'A’ Pasteurized Milk Ordinance,” 2003 Revision.

[13] J. Buchberger, “Zum Einfluss so genannter Umweltfaktoren auf den Gefrierpunkt,” DMZ-Lebensmittelindustrie und Milchwirtschaft, Vol. 121, No. 25, 2000, pp. 10541059.

[14] Bundesministerium der Justitz Deutschland, "Verordnung über die Güteprüfung und Bezahlung der Anlieferungsmilch (Milch-Güteverordnung,” 28 May 2010. http://bundesrecht.juris.de/bundesrecht/milchg_v/gesamt. pdf

[15] H. Bytyqi, S. Muji, U. Zaugg, H. Mehmeti and A. Jahja, "Quality fresh milk standards and Bacterial content to some dairy cattle farms in Kosovo," XIV Congress of the International Society of Animal Hygiene (ISAH) Congress, Vechta, Vol. II, 2009, pp. 633-636.

[16] H. Bytyqi, U. Zaugg, K Sherifi, A. Hamidi, M. Gjonbalaj, S. Muji and H. Mehmeti, "Influence of Management and Physiological Factors on Somatic Cell Count in Raw Cow Milk in Kosova," Veteronarski Arhiv, Vol. 80, No. 2, 2010, pp. 173-183.

[17] Council of the European Communities, "Council Directive 85/397/EEC of 5 August 1985 on Health and Animal-Health Problems Affecting Intra-Community Trade in Heat-Treated Milk,” Official Journal L226, 24 August 1985, pp. 0013-0017. 